\title{
The Brazilian Depression in the 1980s and 1990s
}

\author{
Mirta S. Bugarin, Roberto Ellery Jr., \\ Victor Gomes, and Arilton Teixeira
}

The Brazilian economy experienced two distinct periods after World War II. During the first period, 1957-79, Brazil was one of the fastest growing countries in Latin America. In the second period, after 1980, Brazilian output fell dramatically. Output per working-age person is between 15 percent and 27 percent below trend since the early 1980s. ${ }^{1}$

Brazil is in a depression. In the introductory paper, Kehoe-Prescott (henceforth, this is how we will refer to papers in this volume) define a depression as a large and persistent deviation of aggregate output per working-age person from its trend, such that it falls at least 15 percent within the first decade and remains at least 20 percent below trend. Brazilian gross national product (GNP) per working-age person dropped by more than 15 percent below trend during the 1980s and remained 25 percent below trend in the 1990s (see Figure 1).

In this paper, we study the Brazilian depression using a standard neoclassical growth model. We follow the line of research begun by Cole-Ohanian in their analysis of the Great Depression in the United States. Many authors have shown variants of the general equilibrium growth model to be useful for studying depressions, from those of the interwar period in Europe and North America to those experienced recently in Japan and Latin America. ${ }^{2}$ Bergoeing et al., in their paper in this volume (see also Bergoeing et al. 2002), examine the depression of the Mexican and Chilean economies in the 1980s and 1990s. Kydland-Zarazaga analyze the Argentinean decline in economic activity during 1974-90.

We show that the growth model can replicate Brazil's contraction in the $1980 \mathrm{~s}$ and the 1990s. The standard growth model generates the actual behavior of output, consumption, and investment. It is unable to replicate the behavior of hours worked and capital stock. Once the data are corrected for 
Figure 1. Detrended GNP per working-age person (10-69 years), Brazil (1980-98)

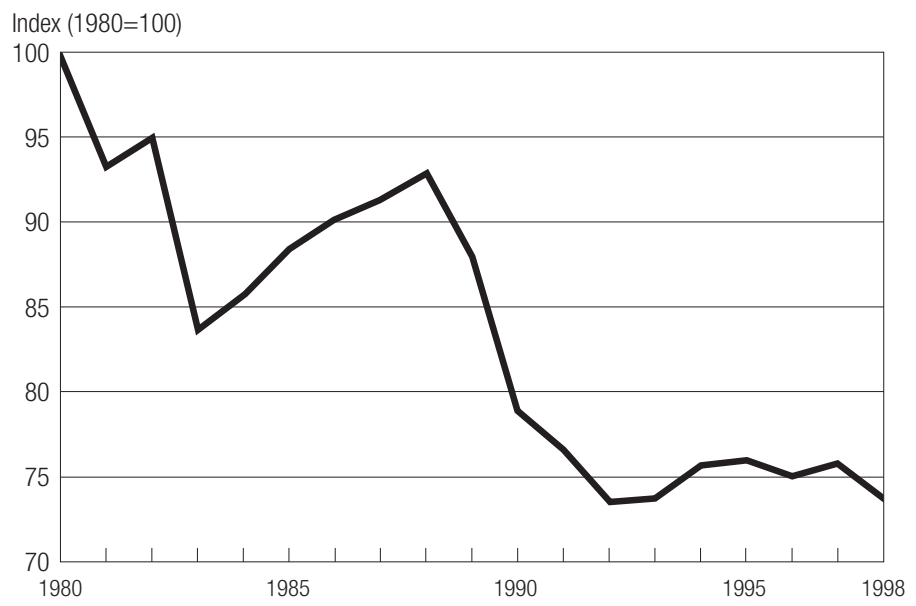

significant distortions of the relative price of investment observed in Brazil, however, the model's ability to generate the observed dynamics of capital and investment significantly improves.

The model economy fails to replicate the dynamics of hours worked, in particular after 1990. We argue that institutional changes introduced by the Brazilian constitutional reform in 1988, especially limits on weekly work hours, help explain the results.

The rest of the paper is divided as follows. First we briefly summarize the main empirical evidence of Brazil's lost decade(s) of the 1980s and the 1990s. We follow with a growth accounting exercise. Next we introduce the standard growth model used for the numerical experiments, then describe the calibration procedure and the numerical experiment. Then we interpret the obtained results and suggest possible ways to solve the problems found in the numerical simulation of the standard model. We conclude with implications of the results for future research.

\section{Empirical Facts of Brazil's Slump (or Depression)}

Among other Latin American countries, Argentina, Mexico, and Chile experienced deep depressions during the 1980s. Argentinean GNP per working-age person dropped 37 percent below trend in 1990 according to Kydland-Zarazaga. Chile's output per worker fell approximately 20 percent below trend in 1983, and Mexico's fell about 40 percent below trend in 1993 (Bergoeing et al., this volume). 
In terms of its persistence, the Brazilian depression is similar to those experienced by Mexico and Argentina in the 1980s and 1990s and by New Zealand during the period 1974-92. ${ }^{3}$ Like these Latin American countries, the Brazilian contraction lasted at least ten years, more than twice as long as the U.S. Great Depression.

According to the definition we use, Brazil's is not a deep depression when compared with other countries. ${ }^{4}$ For instance, Cole-Ohanian report that U.S. per working-age aggregate output went down 38.3 percent below trend in 1933. Amaral-MacGee show a deviation of 40.4 percent below trend for Canada in 1933. For European countries such as Germany and France, per capita GNP fell about 32 percent (in 1932) and 33 percent (in 1939) below trend, respectively, according to Fisher-Hornstein and Beaudry-Portier.

\section{Brazilian Aggregate Output and Its Components}

Here we analyze Brazil's national income accounts (NIA) data. ${ }^{5}$ Since we aim to understand the deviations from trend of the main aggregate series, all data have been detrended. Table 1 presents the detrended indexes of output

Table 1. Detrended per working-age person output and components, 1981-98 $(1980=100)$

\begin{tabular}{|c|c|c|c|c|c|c|c|c|c|}
\hline \multirow[b]{2}{*}{ Years } & \multirow[b]{2}{*}{ GNP } & \multicolumn{2}{|c|}{ Consumption } & \multirow{2}{*}{$\begin{array}{l}\text { Total } \\
\text { invest. }\end{array}$} & \multirow{2}{*}{$\begin{array}{c}\text { Private } \\
\text { invest. }\end{array}$} & \multirow{2}{*}{$\begin{array}{l}\text { Govt. } \\
\text { invest. }\end{array}$} & \multirow{2}{*}{$\begin{array}{c}\text { Govt. } \\
\text { consump. }\end{array}$} & \multicolumn{2}{|c|}{ Foreign trade } \\
\hline & & Nondur. & $\overline{\text { Durables }}$ & & & & & Imports & Exports \\
\hline 1981 & 93.3 & 93.6 & 82.7 & 88.8 & 91.7 & 102.9 & 95.0 & 81.3 & 97.6 \\
\hline 1982 & 95.0 & 96.7 & 97.5 & 88.3 & 86.4 & 95.3 & 104.5 & 70.3 & 80.7 \\
\hline 1983 & 83.6 & 89.0 & 83.3 & 63.4 & 60.3 & 65.5 & 89.1 & 67.6 & 107.0 \\
\hline 1984 & 85.7 & 87.8 & 98.1 & 66.6 & 56.5 & 69.2 & 77.7 & 60.5 & 129.1 \\
\hline 1985 & 88.4 & 84.6 & 90.5 & 84.1 & 72.9 & 86.7 & 95.0 & 55.5 & 119.6 \\
\hline 1986 & 90.1 & 86.5 & 100.2 & 82.1 & 70.6 & 117.3 & 104.7 & 50.7 & 87.8 \\
\hline 1987 & 91.3 & 81.7 & 84.5 & 84.9 & 82.9 & 120.8 & 122.7 & 48.8 & 93.0 \\
\hline 1988 & 92.8 & 83.3 & 73.7 & 81.9 & 83.9 & 117.4 & 123.2 & 44.3 & 105.8 \\
\hline 1989 & 87.9 & 73.1 & 69.1 & 84.8 & 91.9 & 108.9 & 136.8 & 39.2 & 80.1 \\
\hline 1990 & 78.9 & 64.2 & 65.2 & 64.5 & 62.6 & 107.8 & 136.1 & 48.3 & 64.0 \\
\hline 1991 & 76.5 & 67.1 & 53.9 & 63.3 & 60.2 & 92.4 & 114.4 & 53.2 & 71.0 \\
\hline 1992 & 73.5 & 65.2 & 50.1 & 56.1 & 53.0 & 106.2 & 110.3 & 53.9 & 80.9 \\
\hline 1993 & 73.7 & 66.1 & 50.6 & 63.2 & 61.5 & 99.5 & 129.8 & 59.0 & 79.1 \\
\hline 1994 & 75.7 & 70.0 & 59.0 & 68.2 & 64.3 & 113.8 & 134.0 & 60.5 & 71.0 \\
\hline 1995 & 75.9 & 70.3 & 63.7 & 69.8 & 67.1 & 80.1 & 139.0 & 62.8 & 59.2 \\
\hline 1996 & 75.0 & 67.2 & 59.7 & 66.8 & 65.6 & 72.0 & 148.4 & 58.1 & 57.0 \\
\hline 1997 & 75.7 & 68.4 & 59.7 & 69.1 & 69.0 & 69.7 & 144.2 & 65.4 & 62.2 \\
\hline 1998 & 73.6 & 67.9 & 52.6 & 63.6 & 65.5 & 67.4 & 139.2 & 62.4 & 58.8 \\
\hline
\end{tabular}


per working-age person and their components. Numbers in boldface are the lowest level for each series during the period 1990-98.

The above empirical evidence shows a sharp decline in the Brazilian GNP per working-age person. In 1992, twelve years after the beginning of the contraction, the GNP per working-age person was 26.5 percent below trend. There are two subperiods when the economy shows some signs of recovery: during 1985-88 and, much more timidly, from 1993 to 1997. However, these recoveries were not able to bring the economy back to trend. At the end of the 1990s, the Brazilian economy was still 26.4 percent below trend.

All components remain below trend except for government consumption, which increased more than 35 percent above trend from 1981 to 1998. Imports fall more than 60 percent below trend from 1980 to 1989 and remain about 35 percent below trend in the 1990s. The exports index drops 43 percent below trend in 1996.

Table 2 shows aggregate consumption, investment, government expenditures, imports, and exports as a share of GDP for the period 1980-98. Aggregate consumption drops from 59 percent in 1980 to 50 percent in 1990, and in 1998 still does not recover the 1980s share. Investment, on the other

Table 2. Composition of output (as shares of GDP), 1980-98

\begin{tabular}{lccccc}
\hline Years & Consumption & Investment & Govt. cons. & Imports & Exports \\
\hline 1980 & 0.59 & 0.34 & 0.09 & 0.11 & 0.09 \\
1981 & 0.59 & 0.32 & 0.09 & 0.10 & 0.09 \\
1982 & 0.59 & 0.32 & 0.10 & 0.08 & 0.08 \\
1983 & 0.61 & 0.27 & 0.10 & 0.09 & 0.11 \\
1984 & 0.59 & 0.27 & 0.08 & 0.08 & 0.13 \\
1985 & 0.55 & 0.30 & 0.10 & 0.07 & 0.12 \\
1986 & 0.56 & 0.31 & 0.11 & 0.06 & 0.09 \\
1987 & 0.53 & 0.32 & 0.12 & 0.06 & 0.09 \\
1988 & 0.53 & 0.30 & 0.12 & 0.05 & 0.10 \\
1989 & 0.51 & 0.34 & 0.15 & 0.05 & 0.09 \\
1990 & 0.50 & 0.30 & 0.16 & 0.07 & 0.08 \\
1991 & 0.54 & 0.28 & 0.14 & 0.08 & 0.09 \\
1992 & 0.54 & 0.27 & 0.14 & 0.09 & 0.10 \\
1993 & 0.53 & 0.28 & 0.16 & 0.09 & 0.10 \\
1994 & 0.54 & 0.29 & 0.16 & 0.09 & 0.08 \\
1995 & 0.55 & 0.30 & 0.17 & 0.09 & 0.07 \\
1996 & 0.54 & 0.30 & 0.18 & 0.09 & 0.07 \\
1997 & 0.55 & 0.30 & 0.18 & 0.10 & 0.08 \\
1998 & 0.56 & 0.29 & 0.18 & 0.10 & 0.07 \\
\hline
\end{tabular}

Note: Consumption here is the consumption of nondurables. Investment adds the consumption of durables and inventories. Govt cons. is the government consumption in goods and services. All variables are shares of GDP at 1998 prices. 
side, starts with a 34 percent share in 1980 , falls to 27 percent in the initial years of depression, and in 1989 returns to the same level as 1980. In the next eight years, investment drops to 27 percent in 1992, the same figure as in 1983 and 1984, and then rises to about 30 percent of output in the 1995-98 period. This modest drop in the investment share leads to the rise of the capital stock in the subsequent time period (see Table 3). ${ }^{6}$ It is noteworthy that government's expenditure share in aggregate output steadily increases from 1980 to 1998. Imports and exports do not show a clear pattern and remain in 1998 at about the same level as in 1980. In the case of exports, this component of output rises in the first years of the depression but returns to the 1980 level in 1986.

Table 3 presents detrended aggregate output (GNP) and inputs (per working-age person), the capital-output ratio $(K / Y)$, the productivity of hours worked $(Y / H)$, and the percentage of industrial capacity utilization. During the first three years of the contraction, hours worked and capital do not fall below trend, unlike GNP. The latter falls as much as 36.5 percent below trend in 1992 and remains more than 20 percent below trend from then on.

Table 3. Aggregate output and inputs $(1980=100)$

\begin{tabular}{lrrrrrrr}
\hline Years & GNP & Capital & K/Y & Hours & $\begin{array}{c}\text { Average } \\
\text { weekly } \\
\text { hours }\end{array}$ & \multicolumn{1}{c}{ Y/H } & $\begin{array}{c}\text { Industrial } \\
\text { capacity } \\
\text { utilization (\%) }\end{array}$ \\
\hline 1980 & 100.0 & 100.0 & 1.98 & 100.0 & 100.0 & 100.00 & 84.0 \\
1981 & 93.3 & 105.7 & 2.24 & 104.2 & 99.3 & 89.51 & 78.0 \\
1982 & 95.0 & 108.1 & 2.25 & 107.2 & 99.2 & 88.60 & 76.0 \\
1983 & 83.6 & 109.8 & 2.60 & 105.2 & 98.6 & 79.53 & 73.0 \\
1984 & 85.7 & 108.3 & 2.50 & 107.0 & 99.2 & 80.05 & 74.0 \\
1985 & 88.4 & 108.3 & 2.42 & 111.7 & 99.1 & 79.16 & 78.0 \\
1986 & 90.1 & 110.9 & 2.43 & 112.3 & 99.0 & 80.21 & 83.0 \\
1987 & 91.3 & 110.2 & 2.39 & 112.9 & 98.4 & 80.86 & 81.0 \\
1988 & 92.8 & 111.3 & 2.37 & 112.4 & 98.1 & 82.56 & 80.0 \\
1989 & 87.9 & 112.5 & 2.53 & 112.4 & 97.3 & 78.24 & 81.0 \\
1990 & 78.9 & 114.5 & 2.87 & 112.4 & 97.3 & 70.21 & 74.0 \\
1991 & 76.5 & 111.7 & 2.89 & 109.0 & 95.9 & 70.20 & 75.0 \\
1992 & 73.5 & 110.7 & 2.98 & 105.8 & 94.4 & 69.47 & 72.0 \\
1993 & 73.7 & 107.1 & 2.88 & 103.6 & 93.7 & 71.14 & 77.0 \\
1994 & 75.7 & 106.2 & 2.78 & 102.7 & 93.5 & 73.67 & 80.0 \\
1995 & 75.9 & 105.9 & 2.76 & 101.9 & 93.2 & 74.54 & 83.0 \\
1996 & 75.0 & 105.9 & 2.79 & 97.7 & 93.4 & 76.73 & 82.0 \\
1997 & 75.7 & 105.6 & 2.76 & 97.0 & 93.1 & 78.00 & 83.0 \\
1998 & 73.6 & 106.0 & 2.85 & 96.7 & 92.6 & 76.15 & 82.0 \\
\hline
\end{tabular}

Note: GNP, Capital, (total worked) Hours are series per working-age person, Average weekly hours worked is a level index $(1980=100)$, and Industrial capacity utilization is a percentage measure. $K / Y$ denotes the capital-output ratio and $Y / H$ the index of hours worked productivity. GNP and capital are detrended by $2 \%$ growth rate of output per working-age person. 
On the other hand, the input series (measured in terms of per workingage person) move in opposite directions from trend. Capital moves above trend, while total hours worked shows a clear decline, falling 31.1 percent below trend in 1998. The index of average weekly hours worked drops 2.7 percent from 1980 to $1990,1.9$ percent from 1980 to 1988, and more significantly, 4.8 percent from 1989 to 1998 . Industrial capacity utilization starts at 84 percent in 1980, slides to 72 percent by 1992, and recovers to 82 percent in 1998.

Capital intensity $(K / Y)$ increases more than 26 percent from 1980 to 1984 , keeping a share of approximately 2.45 from 1985 to 1989 . With a 16 percent jump from 1989 to 1990, this ratio remains at about 2.8 in the 1990s. The index of productivity declines more than 30 percent from 1980 to 1992. Even though this index slightly improves during the late 1990s, it still remains almost 24 percent below trend in 1998.

Figure 2 depicts the dynamics of detrended aggregate output, capital, and average hours worked, all per working-age person, from 1980 to 1998. The contributions of the two inputs fail to drive up aggregate output. The decline in output and the rise in capital and labor inputs imply a large drop in total factor productivity (TFP) (see Figure 3).

The next section is devoted to quantifying the contribution of these inputs and TFP in order to understand the nature of the Brazilian depression using a standard growth accounting exercise.

Figure 2. Detrended output, hours, and capital series

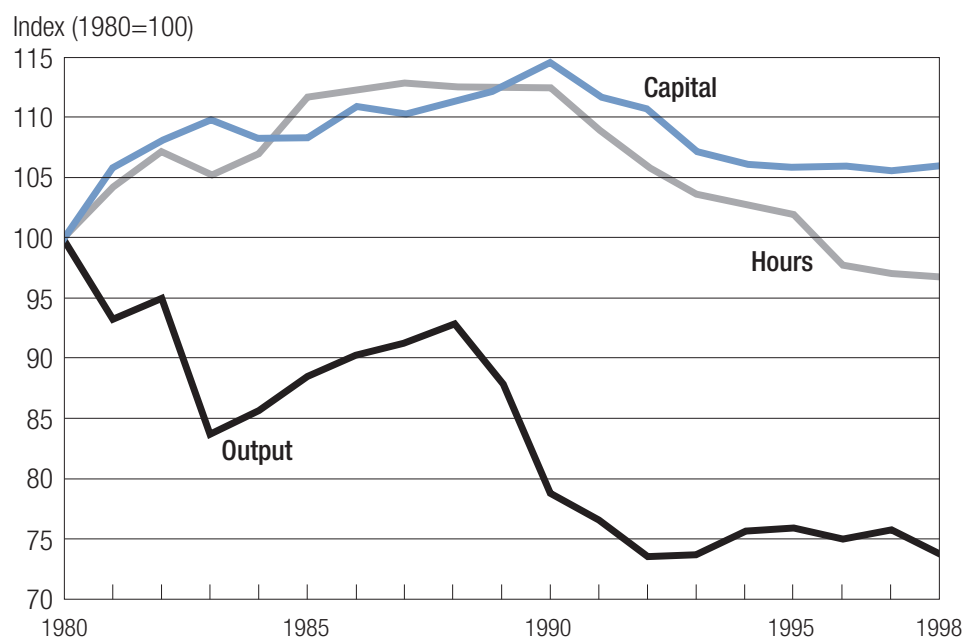




\section{Growth Accounting}

Brazilian NIA data identify the capital share of the economy to be about 50 percent of output. This measure seems to be quite high according to the international evidence (see Gollin 2002). Moreover, there is significant unreported income generated by self-employed and family workers. Therefore, we adjust the capital share to account for this unreported income. We implement an approximation method suggested by the work of Gollin (2002) and Young $(1995,655)$ for East Asian countries using the Brazilian household income survey (PNAD/IBGE). We find that the capital share for Brazil should be approximately 35 percent. Using this parameter value in the following aggregate Cobb-Douglas function, we perform a growth accounting exercise to identify the contribution of capital accumulation, productivity, and labor input, respectively, in the performance of the Brazilian economy.

$$
Y_{t}=A_{t} K_{t}^{\theta} H_{t}^{1-\theta}
$$

$Y_{t}$ denotes aggregate output, $K_{t}$ capital stock, $H_{t}$ total hours worked, and $A_{t}$ total factor productivity (TFP).

Taking natural logarithms of the previous production function and rearranging terms as in Hayashi-Prescott, we obtain the following expression:

$$
\ln \left(\frac{Y_{t}}{N_{t}}\right)=\frac{1}{1-\theta} \ln A_{t}+\frac{\theta}{1-\theta} \ln \left(\frac{K_{t}}{Y_{t}}\right)+\ln \left(\frac{H_{t}}{N_{t}}\right),
$$

where $N_{t}$ denotes the working-age population. From equation (2), the change in real GDP per capita over the period $t$ to $t+s$ can be expressed as

$$
\begin{aligned}
& {\left[\ln \left(\frac{Y_{t+s}}{N_{t+s}}\right)-\ln \left(\frac{Y_{t}}{N_{t}}\right)\right] / s=\frac{1}{1-\theta}\left[\ln A_{t+s}-\ln A_{t}\right] / s} \\
& +\frac{\theta}{1-\theta}\left[\ln \left(\frac{K_{t+s}}{Y_{t+s}}\right)-\ln \left(\frac{K_{t}}{Y_{t}}\right)\right] / s+\left[\ln \left(\frac{H_{t+s}}{N_{t+s}}\right)-\ln \left(\frac{H_{t}}{N_{t}}\right)\right] / s,
\end{aligned}
$$

where the terms on the right side of this equation, from left to right, are the contribution to growth of changes in TFP, in capital intensity, and in hours worked per working-age person, respectively. On a balanced-growth path, the second and the third terms are equal to zero once the capital-output ratio and the hours worked per working-age person are constant; hence, all growth is attributed to changes in TFP for the growth accounting exercise. 
Therefore, as in the work by Bergoeing et al. in this volume, it is assumed in this numerical exercise that changes in output not related to changes in TFP are associated with deviations of investment and work effort decisions from their respective balanced-growth behavior.

Table 4 presents the growth accounting for Brazil. Over the period 1980-98, the Brazilian economy grew at an annual rate of 0.28 percent (per working-age person), well below the average annual growth rate of 4.25 percent observed from 1950 to 1980 . This performance can be attributed to -0.62 percent contribution of TFP, 1.09 percent growth of the capital-output ratio, and -0.18 percent change in hours worked per working-age person.

Table 4. Growth accounting (\%), Brazil (1980-98)

\begin{tabular}{lrrrr}
\hline Period & $Y / N$ & TFP & $K / Y$ & $H / N$ \\
\hline $1980-98$ & 0.28 & -0.62 & 1.09 & -0.18 \\
$1980-88$ & 1.06 & -1.63 & 1.22 & 1.47 \\
$1989-92$ & -4.00 & -4.92 & 2.94 & -2.02 \\
$1993-98$ & 1.96 & 3.45 & -0.11 & -1.38 \\
\hline
\end{tabular}

During the first subperiod, 1980-88, the economy stagnated, growing at an annual rate of 1.06 percent. This performance was driven mostly by the more intensive use of inputs. This is shown by the positive growth rates of the capital-output ratio (1.22 percent) and the hours worked (1.47 percent), which compensate a negative contribution of TFP ( -1.63 percent).

From 1989 to 1992, the Brazilian economy shrunk. Per capita GDP grew at a negative rate of -4.00 percent. During this second subperiod, capital intensity grew by 2.94 percent but was completely offset by (a) a significant negative contribution of TFP (-4.92 percent) and (b) in the hours per working age $(-0.02$ percent $)$.

Finally, the subperiod 1993-98 appears to be a recovery period. Per working age, GNP grew at 1.96 percent. Contrary to previous subperiods, the TFP growth rate of 3.45 percent completely offset the small but negative contributions of input growth rate, i.e., $K / Y(-0.11$ percent) and $H / N$ $(-1.38$ percent).

\section{Numerical Experiments with the Growth Model}

The prior growth accounting shows that for the Brazilian experience, the contribution of changes in TFP is the most important factor behind the country's economic performance. Nevertheless, the same exercise suggests that changes in the investment rate and in the labor input relative to the dynamics of per capita GNP were significant factors as well. 
We calibrate a standard neoclassical growth model with divisible labor to quantitatively assess the contribution of these changes. Theoretically, the agents of the artificial economy generate optimal intertemporal decision rules given a deterministic path of TFP. Then the artificially generated series of optimal decisions are used to assess the ability of the model to explain the observed dynamics.

\section{The Growth Model}

The growth model consists of a closed economy. Denoting all variables in per capita terms, the representative household's utility is defined over sequences of consumption $\{c\}$ and leisure $\{l=1-h\}$ chosen to solve the following problem:

(4) $\max E\left\{\sum_{t=0}^{\infty} \beta^{t}(1+\eta)^{t}\left[\ln \left(c_{t}\right)+\alpha \ln \left(1-h_{t}\right)\right]\right\}$,

subject to the per-period budget constraint. By assumption, our artificial economy has no distortions. Therefore, applying the second welfare theorem, the equilibrium allocation under the planner's problem will be the same as the one obtained under the competitive equilibrium. This theorem allows us to maximize (4) subject to

$$
c_{t}+x_{t}=z_{t}(1+\gamma)^{(1-\theta) t} k_{t}^{\theta} h_{t}^{1-\theta}
$$

were $h_{t}$ represents hours of work, $\eta$ the population growth rate, $\alpha$ a parameter affecting the disutility of working, $\beta$ the discount rate, such that $0<\beta<1, k_{t}$ the per household available capital stock, $\theta$ the capital share in output, and $x_{t}$ investment. Following the notation used in equation (1), $A_{t}=z_{t}(1+\gamma)$, where $z_{t}$ is a stationary component of TFP and $\gamma$ the rate of technical progress. The exogenous shock to productivity, $z_{t}$, is a stationary stochastic process with a law of motion given by

$$
z_{t+1}=1-\rho+\rho z_{t}+\varepsilon_{t},
$$

where $\varepsilon_{t}$ is assumed to be a white noise innovation process and $0<\rho<1$ describes its persistence.

Finally, the law of motion for capital stock is given by

$$
k_{t+1}=(1-\delta) k_{t}+x_{t} .
$$


Therefore, on the balanced-growth path, output, consumption, and capital will grow at the same rate, given by $(1+\eta)(1+\gamma){ }^{7}$

\section{Calibration of the Model}

The model economy is calibrated according to Cooley and Prescott's (1995) procedure. The calibration reproduces the steady-state features of the Brazilian economy before the depression. For 1950-80, the population growth rate is $\eta=2.9$ percent and the average growth rate of technical progress is $\gamma=1.3$ percent. This value of $\gamma$ is obtained according to a 2 percent trend of per working-age GNP and a capital share in aggregate output of 35 percent, i.e., $(1.02)^{(1-0.35)}=1.013$. The depreciation rate is calibrated as $\delta=9$ percent.

The calibration of the discount factor is based on the first-order condition for capital, $\beta=0.90$. This value is derived using the average capital-output ratio for the period $1970-80$, i.e., $(K / Y)_{1970-80}=1.62$. The parameter associated to the disutility of working, $\alpha$, is in turn obtained from the labor Euler equation and the stylized fact that shows agents spend 40 percent of total available time for market activities. ${ }^{8}$ The fraction of time allocated to the market activities is the workweek divided by the total time available to the agents, that is, sixteen hours, seven days per week. Hence, $\alpha$ is set to 1.28. Finally, to calibrate the persistence of the productivity shock given by $\rho$, an $\mathrm{AR}(1)$ regression is run with the detrended TFP (see Figure 3), generating a parameter value of 0.97 .

Figure 3. Detrended TFP, Brazil (1980-98)

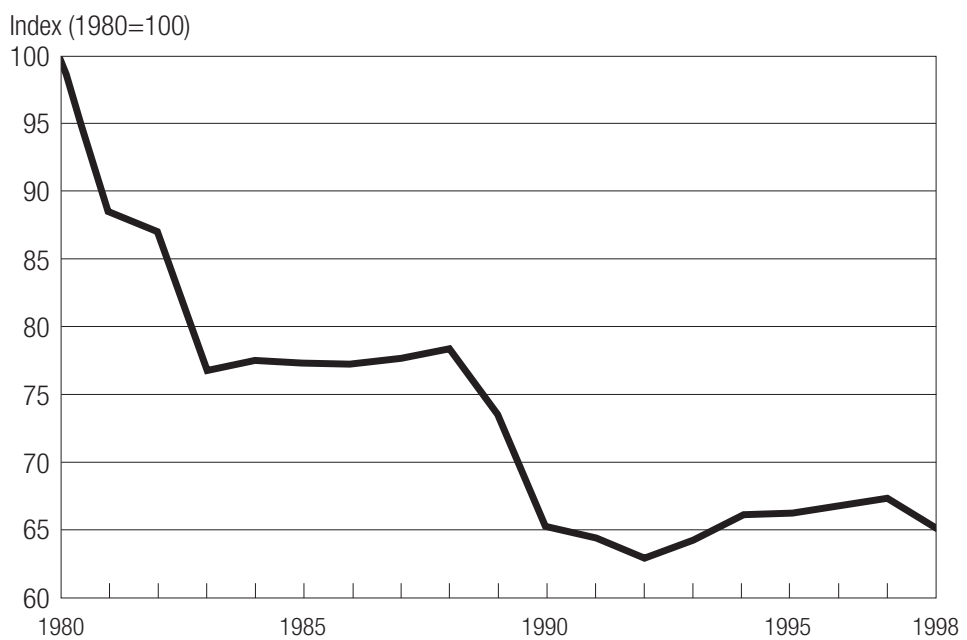




\section{Simulation Strategy and Initial Conditions}

The optimal decision rules are computed using a linear quadratic approximation method to the previous optimization problem translated into a dynamic programming problem. The simulation of the artificial economy begins in 1980. Therefore, we need to set the initial values for the two-state variables $k_{1980}$ and $z_{1980}$. For the technological shock we assume its steady-state value, i.e., $z_{1980}=1$. For the capital stock, we need the actual value in terms of the steady-state variables. To get this value, the steady-state output is multiplied by the actual capital-output ratio of the economy in 1980, i.e., $(K / Y)_{1980}=$ 1.98. Then, for $t=1981, \ldots, 1998$, we use a detrended index of TFP such that $z_{1980}=1$. This sequence and the decision rules of investment and hours are taken to produce the dynamics of the artificial economy.

\section{Findings}

The results, numerically computing the competitive recursive equilibrium of the previous model economy, are analyzed in this section. In Table 5 we show the growth accounting of the simulated series.

Comparing Tables 4 and 5, we see that, for the whole period, the artificial economy generates a deeper recession. This result is due to the behavior of the artificial economy in the first two subperiods in which the depression is overstated by the model. ${ }^{9}$ Despite this, the shape of artificial output is close to the behavior of real output (see Figure 4).

Table 5. Model growth accounting (\%), Brazil (1980-98)

\begin{tabular}{lrrrr}
\hline Period & $Y / N$ & TFP & \multicolumn{1}{c}{$K / Y$} & $H / N$ \\
\hline $1980-98$ & -0.72 & -0.62 & -0.14 & 0.04 \\
$1980-88$ & -1.54 & -1.63 & 0.12 & -0.03 \\
$1989-92$ & -4.38 & -4.91 & 0.78 & -0.25 \\
$1993-98$ & 2.75 & 3.45 & -1.04 & 0.34 \\
\hline
\end{tabular}

As we can see in Figures 4 and $5 \mathrm{a}-\mathrm{d}$, in general the model performs well. In particular, with respect to aggregate output, the model reproduces the falling aggregate output dynamics that we see in the data. The same is true with respect to the movements of consumption and investment as well (Figure 5a and b). Therefore, we can conclude that the technological shocks introduced in the standard neoclassical growth model can fairly explain the performance of the Brazilian economy during the period we consider.

Nonetheless, we should stress that the model fails to match the data for the capital stock and hours worked series (Figure $5 \mathrm{c}$ and d). A closer look at 
Figure 4. Detrended aggregate output dynamics, Brazil (1980-98): data and artificial series

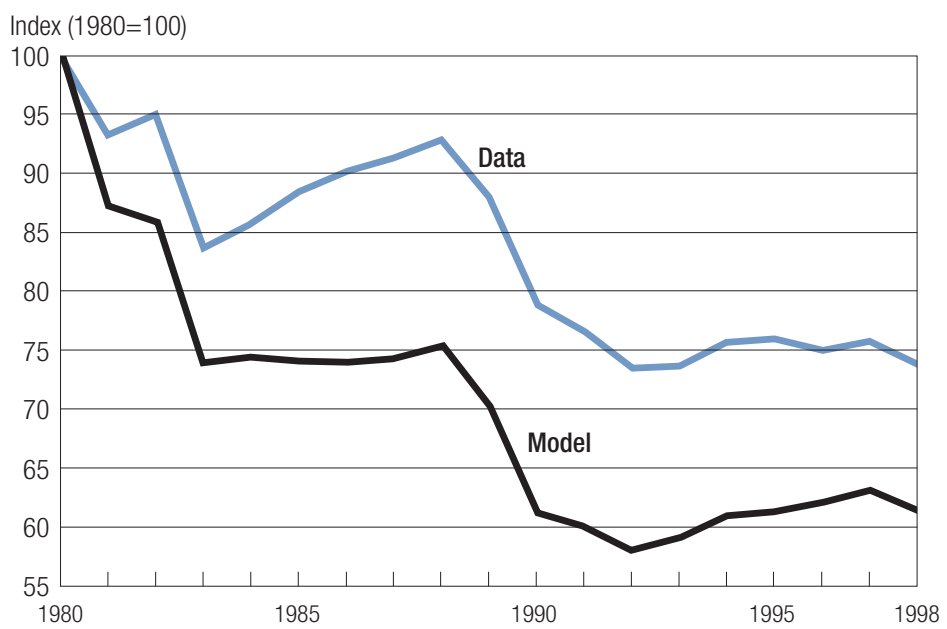

Figure 5. Data and model dynamics: (a) consumption, (b) investment, (c) capital, (d) hours

(a)



(c)



(b)



(d)




the particular characteristics prevailing in the Brazilian economy during the analyzed period is in order. These specifics could explain the limited performance of the artificial economy in regard to these two series.

\section{Analysis of the Findings}

In this section we analyze some features of Brazilian economy that can explain why the model fails to reproduce the behavior of the capital stock and hours worked. From the 1980s up to the early 1990s, the price level of the structures sector ${ }^{10}$ grew much faster than the price level of the economy, ${ }^{11}$ as depicted in Figure 6.

Bacha (1993) suggests that there could be four possible reasons for the increase in the relative price of investment in the 1980s in Argentina, Brazil, and Colombia: the real devaluation of domestic currency; the increases of "listed" prices of investment goods and construction contracts to compensate for higher expected inflation; the substitution of less efficient domestically produced capital goods for more efficient imported ones; and the oligopolistic behavior of domestic capital goods producers.

Figure 6. Relative prices of investment and consumption goods, 1970-2000:

(a) relative price of structures, $(b)$ relative price of machines and equipment, $(c)$ relative price of durable consumption goods,

(d) relative price of nondurable consumption goods

(a)

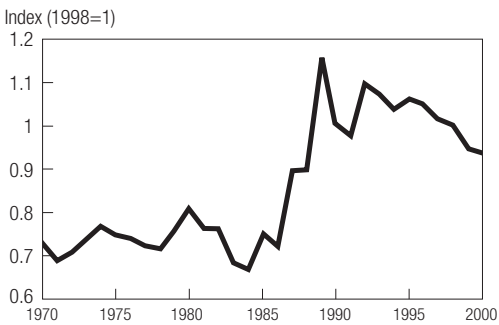

(c)

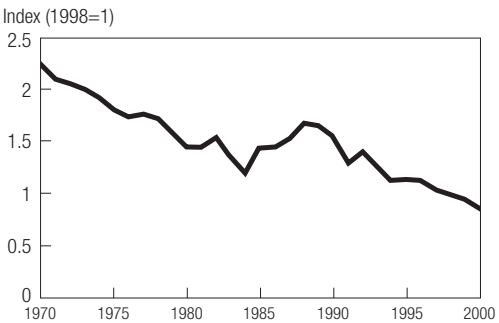

(b)

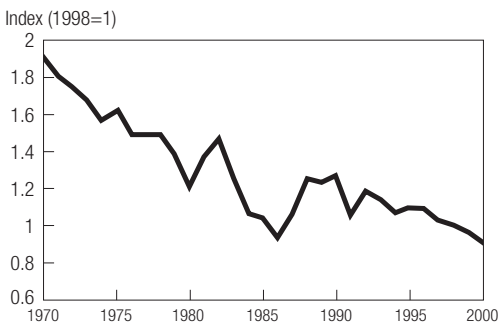

(d)

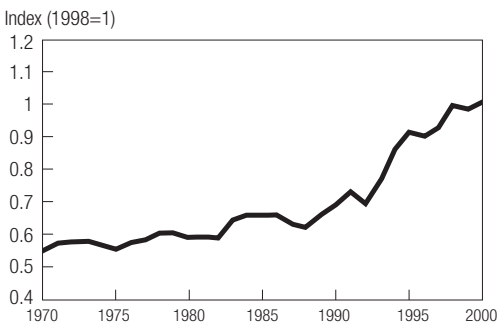


We think that one important reason for the increase in the relative price of investment goods, especially construction in Brazil, is due to several shocks to the economy during the 1980s and early 1990s. During this period, the Brazilian economy had very high rates of inflation. The government attempted to stabilize the skyrocketing inflation rate with so-called heterodox plans. From 1986 to 1991, Brazil experienced six of these (unsustainable) plans. The main instrument of these plans was a price freeze, prohibiting firms from adjusting prices. These plans increased the instability of the Brazilian economy, giving people the incentive to look for hedges. The most common mechanism of protection under this increasingly unstable situation consisted of real estate purchases, such as apartment buildings, that pushed up their relative price.

A second shock that hit the Brazilian economy was the government default on its internal debt in 1990. This default came as part of another heterodox plan, known as the Collor Plan, named after the president who passed this bill in March 1990. Prior to this (expected) default, people tried to protect their savings, shifting demand toward real estate properties. This shift also contributed to an increase in the relative price of investment goods.

This relative price effect has crucial implications, since it can lead to an overestimation of investment in structures. Consequently, it overestimates both the investment and the capital stock series. Since we use the perpetual inventory method, this annual overestimation acts cumulatively on the capital stock series. It drives up the capital stock series, even during the recession, whereas in our

Figure 7. Detrended investment series dynamics, Brazil (1980-98): data, corrected data, and model with corrected data




model economy, capital stock is going down. This effect does not appear in the investment series because it is a flow variable. Hence, each annual overestimation does not sum up over time in this series, as it does with capital.

The recomputed investment series, corrected for these changes in relative prices, is shown in Figure 7. This figure shows three series. The first refers to the investment data without correcting for changes in relative prices. The second series is the same data corrected for the relative price variation. Once the investment series is corrected for changes in the relative price of investment goods to general prices of the economy, this series shifts down. As expected, the overestimation of investment due to this relative price phenomenon is substantial during the second half of the 1980s.

Once the investment series is corrected for relative price changes, the capital stock series is also recomputed. The new capital stock series is shown in Figure 8. This graph shows three series of capital stock. The first one from the top corresponds to the capital stock series based on the raw investment series. The second series is constructed with the investment series adjusted for changes in relative prices. Once the investment series is corrected for this relative price change, the capital stock series shifts down considerably. We compute an artificial series using the standard growth model. In this case, the capital stock obtained with the relative price corrected investment series is used to set the initial capital stock of the model economy. This artificial capital stock series (the lowest series in the graph) is able to mimic the declining behavior of the corrected capital stock data remarkably well.

Figure 8. Capital stock series, Brazil (1980-98):

data, corrected data, and model with corrected data

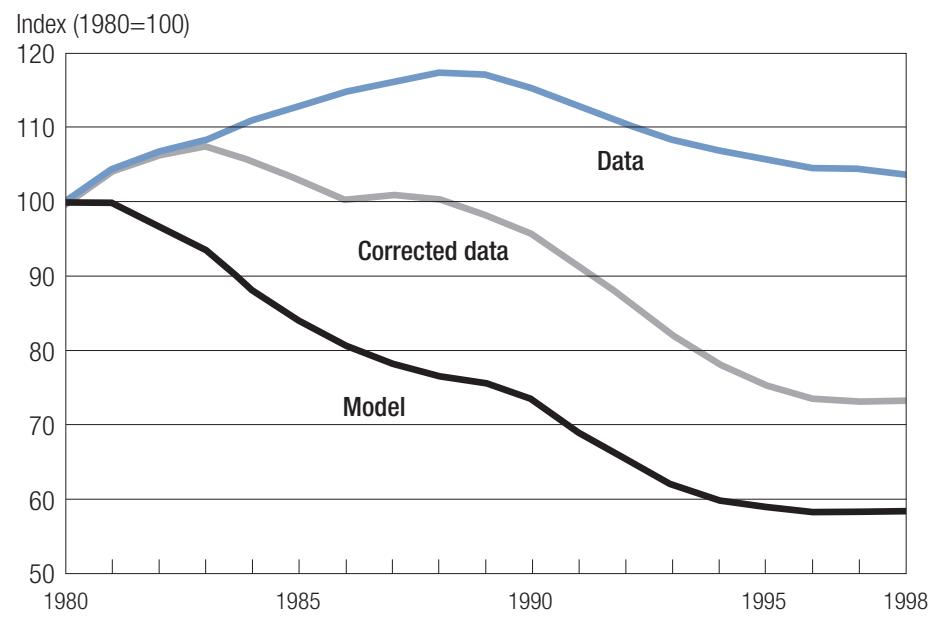


Finally, as stated earlier, the model also does not perform well with respect to the observed series of hours worked (Figure 5d). The new institutional framework introduced by Brazil's constitutional reforms in 1988 may explain the failure of the model to replicate the data. Brazil's new constitution mandated a reduction in the workweek. Moreover, due to an attempt to balance the public sector budget and a significant decentralization of tax revenues brought about by the reformed constitution, many new taxes were created from 1989 on. These tax increases on labor income distort the people's optimal intertemporal decisions. The changes in the tax system increased the Brazilian tax share of GDP from 22.4 percent in 1988 to 31.7 percent in 1998.

This significant increase of labor taxes in Brazil during the period under study, in addition to technology shocks and the legal changes in the workweek, could explain the reduction in hours worked for the period 1988-92 even though productivity started to increase in $1992 .^{12}$

\section{Conclusions}

In this paper we use the neoclassical growth model with exogenous technology shocks to study the behavior of the Brazilian economy during the 1980s and 1990s. In particular, the model indicates that the technology shocks can account for the depression of the Brazilian economy during the 1980s and 1990s.

There are two ways to extend our work. First, we could expand the model to introduce changes in relative prices. Even though we speculate about reasons for the increase in the relative price of investment goods, we think there is room to introduce changes in the model to account for this abrupt jump that we see in the data. Second, we could explicitly consider the government and tax system in the model to assess the impact of changes of labor taxation on the optimal decision of hours worked.

Introducing those extensions should improve the ability of the model to explain the Brazilian depression. First, once we introduce the government into the model economy, we can characterize the government investment decision. Hence, total investment may increase in the artificial economy because government investment does not take into account the marginal productivity of capital when deciding the amount of resources to be invested. Second, introducing taxes may be able to account for changes in labor supply and demand for labor as well.

The final question to be addressed is why productivity did not recover after the external shocks of the 1980s. One explanation of this behavior can be seen in the Bergoeing et al. (2002) hypothesis that government policy distorted the allocations of resources both within and across sectors in Mexico and Chile. In the Brazilian case, this distortion may affect the allocations of both capital and labor. 


\section{Notes}

We have received helpful comments and suggestions from Benjamin Bridgman, Fernando Veloso, Flávio Versiani, and seminar participants at Pontifícia Universidade Católica-Rio de Janeiro (PUC-Rio), the Eighth International Conference of the Society for Computational Economics, and the 2002 Latin American Meeting of the Econometric Society. We are especially grateful to Edward C. Prescott.

1. We assume the working age at 10-69 years instead of 15-65 because we do not have such data.

2. For example, see the papers in this volume and the May 2002 issue of the American Economic Review.

3. For this case, refer to Kehoe-Prescott.

4. The Brazilian experience shows that GNP per working-age person has a trend of approximately 2.55 percent, implied by a growth rate of total factor productivity (TFP) of 1.6 percent for the period 1950-79. Although this trend appears to be much higher than the one corresponding to other Latin American countries such as Argentina, Chile, and Mexico, it is consistent with the fact that Brazil was the Latin American growth leader from the 1950s up to the 1970s. For example, the Brazilian income grew at rates significantly higher than that of the United States during the period 1952-80, from approximately 15 percent of U.S. per capita GDP, reaching almost 32 percent in 1980. This shows a convergence path for the Brazilian economy until 1980. This implies that the depression in Brazil is bigger when the convergence path of the Brazilian economy is considered, i.e., when using 2.55 percent instead of 2.00 percent. For example, for the 2.55 percent trend, the depression in 1998 reaches a trend deviation of 66.87 percent, while for the 2.00 percent trend, the figure is 73.67 percent.

5. See the Data Appendix for more detail about the Brazilian data.

6. To understand the behavior of investment share, we can make a comparison with the U.S. Great Depression. As reported by Cole-Ohanian (see the U.S. chapter, Table 3, in this volume), the investment share drops, from 25 percent of output in 1929 to 8 percent in 1932. This figure represents a drop of 68 percent of investment share. In the first years of the Brazilian crisis, the investment share drops 21 percent; thus, we can state that the drop of investment share was modest in the Brazilian depression.

7. For a more detailed description of the neoclassical growth model, refer, for example, to Kehoe-Prescott, Cooley and Prescott 1995, or Hansen 1985.

8. This value is computed using the Brazilian Household Survey data from 1970 to 1998. See the Data Appendix for details.

9. We will come back to this point later on in this section. We believe that changes in the workweek and in the tax system after 1988 can be used to explain this discrepancy.

10. The relative price of the structures sector is constructed as the ratio of a wholesale price index specific to the structures sector and a general wholesale price index. The same methodology is used to calculate the relative price of machines and equipment, durable consumption goods, and nondurable consumption goods. Structures account for 65.6 percent of the total capital stock, and machines and equipment account for 28.1 percent. 
11. See the work of Carneiro and Werneck (1993) and Bacha (1993) for a study of this relative price in Brazil during the period under study.

12. It seems that the reduction in the workweek is not binding in this period. In our model (see Figure 5d), the number of hours falls even without introducing this new constraint. This indicates that it was optimum for workers to reduce the number of hours worked.

\section{References}

Bacha, Edmar L., ed. 1993. Savings and investment requirements for the resumption of growth in Latin America. Washington, DC: Inter-American Development Bank. Distributed by Johns Hopkins University Press, Baltimore.

Bergoeing, Rafael; Patrick J. Kehoe; Timothy J. Kehoe; and Raimundo Soto. 2002. Policydriven productivity in Chile and Mexico in the 1980s and 1990s. American Economic Review 92 (May): 16-21.

Carneiro, Dionisio D., and Rogério L. F. Werneck. 1993. Obstacles to investment resumption in Brazil. In Savings and investment requirements for the resumption of growth in Latin America, ed. Edmar L. Bacha, 57-102. Washington, DC: Inter-American Development Bank. Distributed by Johns Hopkins University Press, Baltimore.

Cooley, Thomas F., and Edward C. Prescott. 1995. Economic growth and business cycles. In Frontiers of business cycle research, ed. Thomas F. Cooley, 1-38. Princeton, NJ: Princeton University Press.

Ellery Jr., Roberto; Victor Gomes; and Adolfo Sachsida. 2002. Business cycle fluctuations in Brazil. Revista Brasileira de Economia (Brazilian Economic Review) 56 (Abr./Jun.): 269-308.

Gollin, Douglas. 2002. Getting income shares right. Journal of Political Economy 110 (2): 458-74.

Hansen, Gary D. 1985. Indivisible labor and the business cycle. Journal of Monetary Economics 16 (November): 309-27.

McGrattan, Ellen R., and Richard Rogerson. 1998. Changes in hours worked since 1950. Federal Reserve Bank of Minneapolis Quarterly Review 22 (Winter): 2-19.

Muendler, Marc A. 2003. Industry-related price indexes for Brazil, 1986-2002. Unpublished report, UCSD. http://www.econ.ucsd.edu/muendler/html/brazil.html/.

Young, Alwyn. 1995. The tyranny of numbers: Confronting the statistical realities of the East Asian growth experience. Quarterly Journal of Economics 110 (August): 641-80. 